\title{
PROFESSIONALISM IN TEACHING CAREER
}

\author{
Gabriela KELEMEN, Ph.D. \\ Aurel Vlaicu University of Arad \\ gabriela.kelemen@uav.ro
}

\begin{abstract}
The study approaches the issue of high quality training of students who will become teachers. The policy of our faculty is oriented towards the implementation of the most adequate strategies to increase the quality of future teachers 'training. Emphasis is placed on responsibility, efficiency, performance and value found in personal and social success. Our effort focuses on delivering constantly updated and improved study programmes. However, this would not be enough without the students full engagement in their professional training by involving themselves in training along with thorough work. The $21^{\text {st }}$ century calls for high quality teacher training given the competitiveness on the labour market and the progress of scientific conquests in all areas. It is necessary to consider and implement a curriculum that develops excellent competences in our students. It should bring a significant contribution to efficient training of future teachers in theoreticalscientific, methodological and practical terms so that teachers would be able to use their competences in a creative manner in the classroom. They should be taught to blend teaching with the students needs. The performing competences result in students' positive learning results.
\end{abstract}

Key words: professionalism, competence, performance, quality

\section{Educational performance}

Teaching is constantly subjected to challenges such as low income, many working hours, social pressure in a competitive society where emphasis is placed mainly on economic efficiency. Thus, one has the feeling that the teaching profession is insufficiently valued by the society. Lately, scholars talk more and more about an education crisis which raises questions about the training of teachers as main actors of the educational process. Criticism regarding the quality of future teachers initial training is another common aspect nowadays. Thus, it is necessary to develop a new vision of professional standards for teaching career and the share between initial and continuous training and the professional evolution should be reassessed. Professional standards related to the level of teacher training refer to the 
expected quality of teachers` work differentiated according to teaching positions, level of education and expertize. Competences require a certain level of performance in teaching activity and they can be of two types: cumulative and progressive competences. It means that students will acquire competences along with knowledge, skills, aptitudes and attitudes, experiences but also by manufacturing in a personal, creative and specific manner the realities from classroom practice.

The current society is a society guided by unprecedented changes. It is a society of knowledge and calls for rapid adjustment, mobility, flexibility and efficiency as response to rapid changes in the environment. Higher education which trains future teachers should consider these social premises in the process of teacher training. Teachers' initial training is oriented towards professionalism in teaching and its aim is the students ability to train constantly as stated by the famous Czech pedagogue J. A. Comenius in the $17^{\text {th }}$ century tota vita schola est. Although „University turned into from an institution of intellectual development into a "company" capable of producing individuals suitable for immediate and efficient professional and social insertion"(Bocoş, M., Albulescu, I. 2008, p. 36), initial training through undergraduate and master studies is considered insufficient.

\section{The model for professionalism in teaching career - from aptitude to pedagogical competence}

Current social tendencies along with the rapid pace of changes, frequent legislation changes and instability of legal educational framework, teaching practice guidance and other aspects, call for a reconsideration of teachers professional and social status by reassessing and ranking their professional roles and duties. Changes in didactic/methodological training of future teachers are necessary according to relevant research and experiences in the didactic field.

Our faculty has followed certain strategic principles in teachers` initial and continuous training in the last decades:

- development of initial training system based on a set of competences and quality standards, aiming professionalism in teaching career;

- reshaping the balance between theoretical and practical part of the curriculum for teacher training (practical orientation - teaching practice);

- development of a mobility oriented initial training system;

- implementing partnership in inter-institutional relations.

- development of postgraduate programmes (master studies) for initial teacher training; 
- orienting the training systems towards pedagogic competence and educational performance;

- adapting the teachers` continuous training system to the European pattern of continuous professional development/ lifelong learning;

- development of professional mobility and development programmes through the system of transferable professional credits;

- emphasising the role of E-learning, as support in teachers' continuous training system

High quality or top training requires the improvement of students training level through student-teacher interaction. The reason for such interaction is the development of students psycho-pedagogical and methodological abilities.

Performing schools are those which have performing teachers who use the most appropriate teaching strategies and determine their students to have high quality school performance. A teacher who promotes a system of values based on mutual respect, trust, interaction, who makes students think critically, discover knowledge and interact with their peers and who creates a warm atmosphere will improve the quality of learning in his/her class.

\section{Optimizing students` professional training}

We applied 4 sets of questionnaires on a sample of 60 Master students to see their opinions about the quality of future teachers ' professional training. Our aim was the identification of students 'perception regarding:

1. strong points of initial training programme for teaching profession;

2. the share of modalities of accessing professional training;

3. the importance of each training stage for teaching career;

4. the causes for poor quality training for teaching career.

After interpreting the answers in the below listed charts, we can identify relevant elements in students`answers. 
STRENGTHS OF TEACHER TRAINING

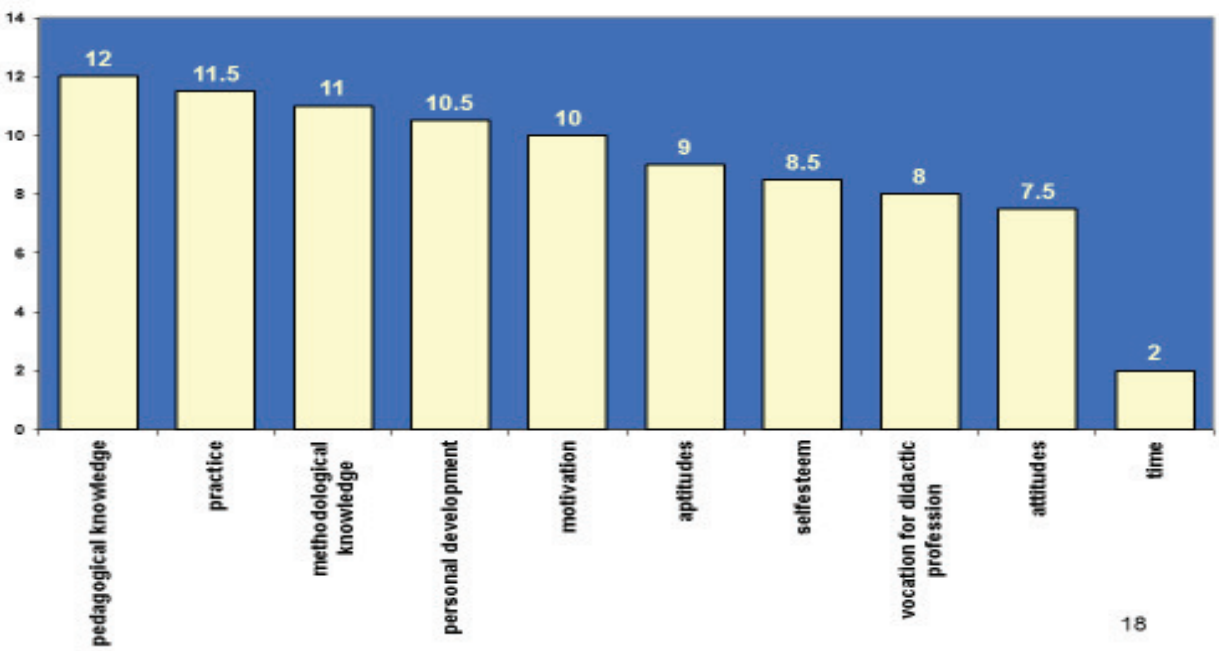

Fig.no.Strengths of teacher training

We observe that students place emphasis in their professional training on knowledge, i.e. acquisition of pedagogical knowledge. Practice is placed on the second position as students consider that practice along with methodological training lead to increased quality of training. Personal development, aptitudes and motivation share the same position along with vocation and attitude. Most students do not consider time management an important skill in the future teachers` professional training.

\section{MODALITIES OF PROFESSIONAL FORMATION IN} STUDENTS' OPPINIONS

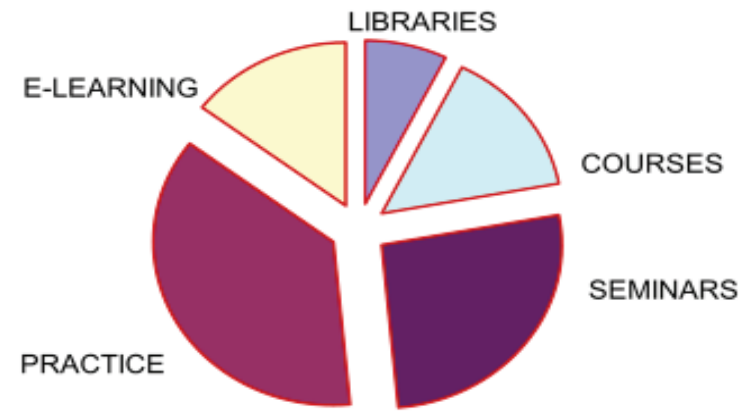


Figure no. Modalities of professional formation in students' opinions

In terms of students ' perception of the share of each manner of professional training, we notice that they prefer practice and seminars followed by courses and e-learning, which share the same weight. Less appreciated is library study.

\section{THE STUDENTS'POINT OF VIEW CONCERNING THEIR PROFESSIONAL TRAINING}

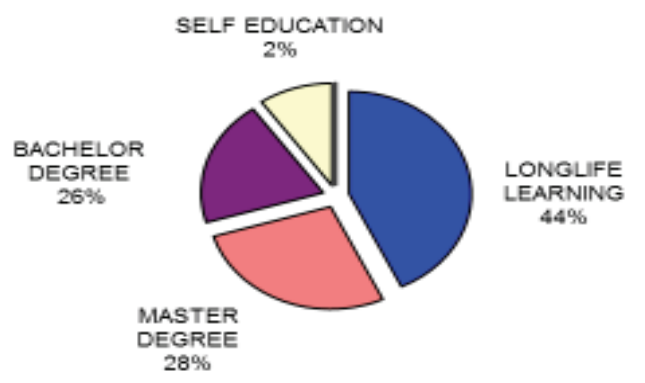

Fig.no.The students 'point of view concerning their professional training

\section{CAUSES OF POOR QUALITY IN INITIAL TEACHER TRAINING}

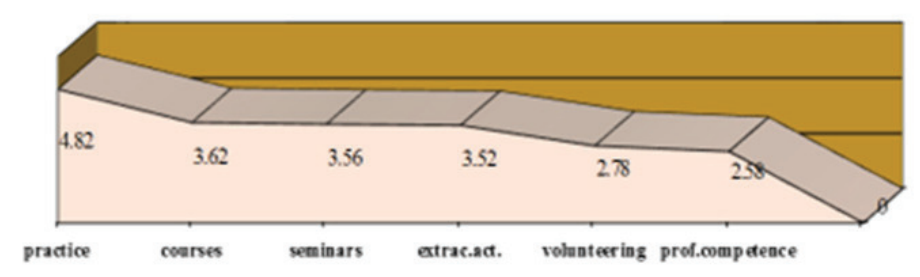


Journal Plus Education, ISSN: 1842-077X, E-ISSN (online) 2068-1151 Vol XVI (2016), No. oct. pp. 148 - 154

Fig.no. Students point of view upon causes of poor quality in initial teacher training

We notice that students identify the following causes for poor professional training: in descending order the low number of practice hours, followed by courses, seminars and extracurricular activities on the same position. Volunteering and trainers` professional competences share the same weight in students`opinions.

\section{What should we do}

Studying the outstanding educational results achieved by Nordic Countries, especially Finland, and the spectacular students` results at PISA tests, Pasi Sahlberg the CEO of Centre for International Mobility and Cooperation considers that the leading role in obtaining such results is played by the teachers, who have managed to train performing students. Teacher training in Finland, after 1970 is conducted by universities and emphasis is placed on:

- Strong preparation in content and pedagogy;

- Integration of theory, research, and practice;

- Professional Learning and Development;

- The Teacher's Tools: Curriculum and Assessment (Pasi Sahlberg, 2010).

Training for the teaching career focuses on the rigorous development of education which blends theoretical training with pedagogical research. Training programmes for future teachers contain knowledge of pedagogy, methodology and education theory. However, they also aim to develop pedagogical research skills at students, who are encouraged to follow their own paths of pedagogical research i.e. teaching practice under an experimented mentor`s guidance.

Proper financial funds for education, decent salaries for teachers and proper working conditions would be a plus for a successful educational process.

Students 'motivation for a better training is stimulated by a quantity and quality reconsideration of teaching practice.

The teaching profession has become a respected profession and teachers have acquired considerable autonomy and authority, including responsibility for curriculum design and students assessment. Such aspects bring about responsible behaviour, as well as continuous analysis and training of their teaching activity.

\section{Conclusions}

High level professional training creates the prerequisites for a successful career. A proverb written by Lao-Tzu says the following: "Ifyou tell me I will listen. If you show me I will see. If you let me experience, I will learn." 
We believe that a reconsideration of early teaching period or career debut by introducing the assistance and counselling system (introduction of a mentoring system) would be an important factor for a thorough training for the teaching career. Scholars have discussed the increase of efficiency in professional training at the international reunion for education. They have also emphasised the role of teachers, who do not only transmit easy assimilated knowledge but mostly they place students in situations where they have to use critical thinking, filter information, be actively involved in learning, develop assertive communication skills and adopt prosocial attitudes (OECD, 2011).

\section{References:}

Bocoş, M.; Albulescu, I. (coord.) (2008), Studii de pedagogie universitară, Editura Presa. Universitară Clujeană, Cluj-Napoca.

Chis Vasile, Pedagogia contemporana. Pedagogia pentru competențe, Casa Cărții de Stiință, Cluj-Napoca, 2005.

Dan Potolea; Ioan Neacsu; Romita B. Iucu; Ion-Ovidiu Pânişoară, (2008), Pregatirea psihopedagogica. Manual pentru definitivat și gradul didactic II, Editura Polirom, Iași.

Duță Nicoleta, (2012), Cariera universitară, fundamente și strategii formative, Editura Universitară, București.

Iucu R., (2004), Formarea cadrelor didactice: sisteme, politici, strategii, Editura Humanitas Educaţional, Bucureşti.

Voiculescu, Florea, (2004), Analiza resurse-nevoi şi managementul strategic în învăţământ. Bucureşti: Ed. Aramis.

Zgaga Pavel; Ioan Neacşu; Simona Velea, (2007), (coord), Formarea cadrelor didactice. Experienţe Europene, Editura Universitară, București.

European Higher Education Area (2009). Bologna Process. Vienna: Austrian Federal Ministry of Science and Research. Available at:

http://www.ond.vlaanderen.be/hogeronderwijs/bologna/documents/Bologna booklet.pdf.

Sahlberg, P. (2007). Education policies for raising student learning: The Finnish approach. Journal of Education Policy, 22(2), 147-171.

Sahlberg, P. (2010). The Secret to Finland's Success:Educating Teachers. Available at:

https://edpolicy.stanford.edu/sites/default/files/publications/secretfinland\%E2\% $\% 0 \% 99$ s-success-educating-teachers.pdf

Higher Education Academy (n.d.) Professional Standards Framework (UKPSF). Available at

http://www.heacademy.ac.uk/assets/documents/ukpsf/UKPSF_2012_v2_050 912_1044.pdf. 